\title{
The Piro canoe. A preliminary ethnographic
} account

Peter Gow

\section{(2) OpenEdition \\ Journals}

Electronic version

URL: https://journals.openedition.org/jsa/12129

DOI: 10.4000/jsa.12129

ISSN: 1957-7842

\section{Publisher}

Société des américanistes

\section{Printed version}

Date of publication: 31 July 2012

Number of pages: 39-61

ISSN: 0037-9174

\section{Electronic reference}

Peter Gow, "The Piro canoe. A preliminary ethnographic account", Journal de la Société des américanistes [Online], 98-1 | 2012, Online since 10 June 2015, connection on 02 September 2022. URL: http://journals.openedition.org/jsa/12129 ; DOI: https://doi.org/10.4000/jsa.12129 


\title{
THE PIRO CANOE. A PRELIMINARY ETHNOGRAPHIC ACCOUNT
}

\author{
Peter GOW *
}

The article provides a preliminary account of the canoes made and used by the Piro (Yine) people of the Urubamba river in Peruvian Amazonia, with a particular focus on the processes of construction, naming and crewing. The canoe, among these people, is a basic model of affinity, both male-female and male-male. The canoe and canoe journeys are a basic social model of space for these people, serving a symbolic function that usually falls to house and village space in indigenous Amazonian societies. [Key words: canoes, Piro (Yine), Amazonia, affinity, spatial symbolism.]

La pirogue piro. Un premier compte rendu ethnographique. Cet article a pour objectif de fournir un premier compte rendu sur les pirogues fabriquées et utilisées par les Piro (Yine), groupe vivant près du fleuve Urubamba, en Amazonie péruvienne. Y seront décrits les processus de construction, de nomination et de formation de l'équipage. Chez les Piro, la pirogue peut être considérée comme un modèle de l'affinité, dans les relations entre hommes et femmes, mais aussi entre hommes. La pirogue comme les voyages en pirogue correspondent à un modèle d'organisation sociale de l'espace, servant une fonction symbolique qui, dans les sociétés amazoniennes indigènes, revient, habituellement, à l'espace de la maison ou à celui du village. [Mots-clés : pirogue, Piro (Yine), Amazonie, affinité, symbolisme spatial.]

La canoa piro. Un informe etnográfico preliminar. Ese artículo propicia un informe preliminar acerca las canoas hechas y empleadas por el pueblo piro (yine) del rio Urubamba de la Amazonía peruana, con un enfoque especial en los processos de la fabricación, el nombreamiento y la composición de la tripulación. La canoa, entre este pueblo, es el modelo por excelencia de la afinidad, tanto entre hombres y mujeres como entre hombres. La canoa y los viajes de canoa representan, para este pueblo, un modelo social básico del espacio asumiendo así una función simbólica que normalmente recae en los espacios de la casa o del caserio en las sociedades indígenas amazónicas. [Palabras claves: canoa, piro (yine), Amazonía, afinidad, simbolismo espacial.]

* University of St Andrews, St Andrews, Fife KY16 9AL, United Kingdom [pgg2@standrews.ac.uk].

Journal de la Société des Américanistes, 2012, 98-1, pp. 39-61. C Société des Américanistes. 
Los piros son el trome del rio (The Piro people are the wonder of the river).

A man from Quiteni, Alto Urubamba

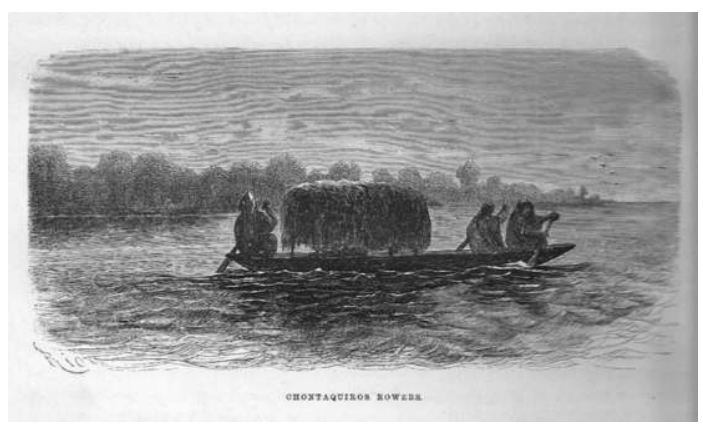

A Piro canoe and its crew, 1845 (Marcoy 1875).

In common with all indigenous Amazonian peoples living along the major rivers of the region, the lives of the Piro (Yine) people of the Bajo Urubamba river in Peru would be impossible without canoes. This essay seeks to provide an account of certain anthropologically salient features of canoes among these people. It is one of the first products of a research project on «A transforming landscape of journeys: Piro long distance trading in the 19th century ». As will be noted, canoes played no role in the title of the project, and very little in the original proposal for funding. It was only in the course of doing the research that canoes began to really attract my attention.

Ethnographic accounts of canoes should be important in descriptions of indigenous Amazonian peoples, but they are not. The following is from Robert Lowie's definition of the Tropical Forest cultures, from the third volume of the Handbook of South American Indians, that on the « Tropical Forest Tribes »,

The very wide distribution of certain traits in the area is correlated with navigation. Thanks to their mobility, the canœing tribes were able to maintain themselves in the midst of boatless populations, to travel with ease over periodically inundated tracts, and to diffuse their arts and customs over enormous distances. The combination of this technological factor with natural conditions has produced the extraordinary leveling of culture («acculturation » in German parlance) in this area. (Lowie 1948, p. xxvii)

One might think that such importance would have made the study of canoes central to the efforts of ethnographers of the region, but this has not been so. There is one unpublished manuscript on the technical aspects of the « watercraft of Amazonia » by Roop (1935), based on primary ethnographic sources ${ }^{1}$, but otherwise remakably little literature on the topic. Indeed, Steward, in the fifth 
volume of the Handbook, entitled The comparative anthropology of South American Indians, wrote that it contained,

[...] many obvious and regrettable omissions among the articles on material and social culture; for example, dress, boat types, featherwork, stonework, birth and death customs, music, dancing, mythology and others. (Steward 1949, p. xxii)

Since then, many of these topics, dress, featherwork, birth and death customs, music, dancing, and mythology, have gone on to become central to the regional ethnographic literature, but « boat types » has not attracted much interest.

The absence of any discussion of canoes in recent ethnographies of indigenous Amazonian peoples has four probable causes:

1. Most recent ethnography has been done with peoples living away from large navigable rivers and hence not makers or users of canoes, because these are the least « acculturated».

2. Central concern with social organization, associated most clearly with village or house layout or symbolism.

3. Canoes are how you get there, and not particularly interesting thereafter.

4. The processes of colonialism are probably most peculiarly destructive of the specific media, canoes, by which a large part of a colonized world habitually sought to connect with its exterior.

I can claim no great virtue in this regard, for as I have said, I embarked upon this research with very little sense that canoes would be of much interest. At most, I had noted in my analysis of Piro women's design painting as an ontogenetic structure for which canoe making might be the male equivalent (Gow 1999).

In what follows, I have drawn inspiration from Lévi-Strauss' short but extremely insightful discussion of canoes in The origin of table manners (LéviStrauss 1978), and from Munn's work on Gawa (Papua New Guinea), especially her work on canoes (Munn 1977, 1986) ${ }^{2}$. I have also gained a great deal from an extensive reading in the literature, both about Amazonia, the Americas and elsewhere, and from conversations with the persons named in the acknowledgments: I have largely eschewed such wider comparisons here, and hope to address such issues elsewhere. My main concern here is ethnographic, and to appeal for such ethnographic accounts of canoes for other peoples.

\section{To go AND TO STAY}

Matteson (1954), the SIL linguist missionary, records of Piro people,

Travel is irresistibly pleasant [...] Poling is hard work, but the men seem to enjoy it perhaps because they started it as play. Even two year-olds may take a little rod and play poling as the canoe moves along. Men shout and laugh in the hard passes. « How do you 
know Pablo is upriver if you didn't see him? » « Oh, I heard him laughing on the other side of the island ». (ibid., p. 30)

There are two Piro words for « to travel »: yagapota, « to travel by trail », and yagapgata, « to travel by river, to journey », and it is clear that the joys of travel refer exclusively to the second. Indeed, I cannot imagine Piro people ever describing «travelling by trail» as pleasant, far less irresistibly pleasant. For Piro people, long-distance movement seems to be existentially pointless unless it involves water and canoes. For them, the value of the verb « to go » seems to derive from its entailment of flowing water and canoes. For them, any place that you can get to by canoe is worth going to, while any place you have to walk to probably isn't.

As I have discussed extensively elsewhere (Gow 2001), a central Piro social value is gwashata, translated into local Spanish as vivir bien, « to live well ». The Piro word literally means, « to reside continuously, to just stay ». It refers to a contented everyday life in a village full of congenial kinspeople. Its importance can be seen in the following endlessly repeated scene: a visitor asks someone sitting in their house, ;gi pixa?, « what are you doing?», to which the expected reply is gewno, " nothing ». The Piro forms literally mean, « what is wrong with you? » and, « I am here ». The exchange raises the possibility of something being wrong, something that might disturb gwashata, «staying and doing nothing more », while the reply asserts contentment, " I am here », " I am residing continuously ». Yet, for Piro people, travelling is irresistably pleasant. I will try here, somewhat obliquely, to resolve this apparent contradiction.

Piro people are strongly oriented towards life along large rivers. All Piro villages are positioned with regard to sand beaches, ksatu. Piro villages are located on landforms that would be called levees on the Mississippi, that is, old river beaches that are now above water during most of the rainy season. Levees are formed as very slow moving flood waters drop their very high sediment load. As long as they continue to be seasonally flooded at the highest water level, levees continue to rise. Piro people are very tolerant of their villages being seasonally flooded. Similarly, the staple vegetable crop of Piro people, plantains, grows well on old beach land, and are relatively tolerant of short periods of flooding. The protein complement of plantains in nikchi potu, " real food », a Piro meal, is overwhelmingly supplied by fish. While most Piro men and some Piro women hunt, and all like to eat forest game, life without fish to eat is unthinkable.

\section{A Piro social riverscape}

In the 19th century, Piro-speaking people were spread out over a vast area of Southwestern Amazonia, and this remains true today despite some dramatic changes (the following is a summary of the first chapter of Gow 1991). There 
were the Piro of the Bajo Urubamba, the Piro of the Cushabatay far to the north on the Bajo Ucayali river, the Piro and Mashco of the Manú river to the southeast, the Manitineri on the middle and upper Purús and the Acre rivers to the east, the Cushijeneri in the headwaters of the Purús and Curanja rivers to the east, and the Kuniba on the Yuruá river to the far northeast. The map-distances between these populations was in the order of hundreds of kilometres. All these peoples spoke dialects of the same Southern Arawakan language and were in constant contact with each other for trading purposes. Each of these Piro-speaking peoples were associated with a particular river or stretch of a river, so I will call them « river groups ». This is in line with the way Piro people themselves think about, say, Koshawatu gwachine, Gorowampa gwachine, Yako gwachine, etc. " those who live on the Cushabatay river, the Urubamba river, the Yaco river ».

The nature of trading between different river groups is very poorly understood. In the 19th century, the trading expeditions of members of the «Urubamba river group » south into the Alto Urubamba and the Andes and north towards the Amazon mainstream and the Bajo Huallaga river to the northwest are fairly well known insofar as these targeted literate colonial agents (in all three areas, Franciscan priests), but much less is known of trading with other indigenous peoples, such as the Asháninka to the immediate west on the Tambo river and its affluents. To the east, very little is known at all about the Piro river groups until either shortly before the massive disruption caused by the rubber extraction economy, or indeed as a consequence of that industry. We therefore see this eastern trade at the very moment of its violent destruction or transformation.

However, it seems that the various Piro river groups had long engaged in peaceful trade with each other, including making long-distance visits to each others' territories for that purpose. Significantly, the various different river groups seem to have been spaced non-randomnly, being consistently about a three-month round trip from each other. These three month periods correspond to the height of the dry season, the time of maximal fish availability and ease of travel upriver. It is likely that these expeditions were coordinated with the cycle of gardening: new gardens could be felled before the travellers set off, and then burned and planted as they returned at the end of the dry season.

The result was a trade system perhaps unique in Amazonia. Long-distance trading is well-attested for much of Amazonia, but I know of no other example where speakers of a single language were spread out over a very large area but in relatively small and highly discrete territories, which were in turn interdigitated among the territories of speakers of quite different languages, while at the same time maintaining very close relationships with each other. There seem to be two strong facilitating reasons for this remarkable intra-ethnic long-distance trading system. Firstly, this trading system, and the centrality of Piro-speaking people to it, unquestionably emerged due to a geographic accident: the major right-bank 
tributaries of the Urubamba-Ucayali rivers and the Yuruá, the Purús, and the Madre de Dios all rise in the same small upland area in what is now eastern Peru. Geologically, this upland is almost certainly the easternmost expression of the general process of Andean orogeny or mountain-building, as the earth's crust is being buckled up by tectonic forces far to the west.

This geographic feature means that tributaries of four of the major southern tributaries of the Amazon rise very close to each other in a relatively small area. For people who had the technological means and the social desire to exploit this geographic singularity, it offered remarkable potentials in turn. For Piro-speaking peoples, the social desire was provided by trading, a very complex and fascinating topic which I do not really address here. The technological means were their canoes, which I do.

\section{Piro geography}

As I noted, Piro people do not like to travel any distance on foot (except when hunting), and the term for "traveller" is kyagapgakleru, "one who goes by river », which gives a sense of dominance of rivers in their sense of space and of canoes in their sense of movement. «To travel, to journey » is therefore to move along rivers and between river systems. Cardinal directionals do exist in Piro, but they are seldom used in everday contexts. " East» and « west » are descriptive, « where the sun comes out» and « where the sun goes in »: this distinction is cosmologically important. The words for north and south seem to be neologisms, probably generated by North American missionaries translating the Bible.

The key Piro directionals are gawaka, « upriver», mala, " downriver », wakanu, " on the opposite bank », and pa sreta, " on the other side " (that is, in another river system). With these four terms Piro people can specify all important spatial relations at the level of their lived landscape. Of these directionals, easily the most important are " upriver » and " downriver ». With these two directionals, Piro people can specify virtually all significant spatial relations in the landscape, however large.

Four verbs correspond to these four key directionals. Of these, koprugata, « to go to the opposite bank », is probably the most parochial, since it refers to minor local movements. Kopruta, « to go to the other side », is probably the most arcane, for it refers to movements between river systems, the process we call portaging, that is, physically pulling a canoe overland from the headwaters of one river system into the headwaters of another. This mode of movement is sufficently alien to most English-speakers that our verb is a loanword from Quebecois, that is, Montreal French. In everyday life, paligata, « to go upriver », and gisurna, « to go downriver », are the dominant modes of spatial dislocation. These two verbs are strongly contrasted by their travel costs, against or with the river current. 
The maximal landscape for Piro-speakers is tye gogne, " this world», and includes the totality of all rivers, which are ultimately seen as tributaries of a single river, wenu, called on the Urubamba, yami. Given the manner in which Piro-speakers understand space as a series of interconnected places spread along a river, they assume that all places are on this river in one way or another. Thus Piro people would often ask me if Scotland is before or after England, or whether Rome is before or after China. By this they meant whether, travelling on the implicit world axis of the one river, one arrives at England first, then Scotland, and first at Rome and then at China.

This set of places along a world river constitutes tye gogne, " this world », for Piro people, and is opposed to pa sreta gogne, « the world on the other side ». This is the sky, tengognewaka, but not the sky that we can see. " The world on the other side » is the sky as seen by its inhabitants, and consists of a river with associated settlements and their divine inhabitants. It is along this river that the sun journeys in his canoe during the day. At night he returns through the underworld of the Mtengat-wenne («The Shallow River »). These wider cosmological frames are discussed further in Gow (2001), but this brief account shows how dominated Piro people's ideas of space and place are by flowing water.

\section{Canoe-making}

At the time of my fieldwork from 1980 onwards, Piro canoe-making had come to be very strongly influenced by the growing importance of the peque-peque style of outboard motor. The peque-peque motor is a remarkable invention, which deserves but has apparently never received a study in its own right. The peque-peque motors used on the Bajo Urubamba at the time of my fieldwork were assembled in Pucallpa in an audacious bricolage of the most diverse parts: Briggs-Stratton lawnmower engines from Wisconsin, scaffolding tubes, steel rebars for reinforced concrete, cheap aluminium propellers, wood, etc. Brilliantly adapted to the local navigational challenges, these motors have caused a number of transformations in the manner in which canoes were made during my fieldwork.

In the light of this, I give priority to the account of canoe-making given by Matteson for the period of the late 1940's/early 1950's, before the peque-peque motor had emerged. She wrote as follows,

The biggest item in woodcraft is the dugout canoe. The selection of an appropriate tree for the making of a new canoe is very important. The preferred woods are cedar (kanawa, the word for canoe), mahogany, and catahua, the tree whose white sap causes sores and blindness. The cumala, copaiba, lagarto caspi, palo de cruz, cedro blanco and another cedro with a distinct name in Piro are also used for canoes, as well as two trees not identified with names in Spanish. Canoes made of one of the latter are said not to 
last long. Not only is the type of wood important, but also the size, shape and health of the tree. Often the tree selected is at such a distance from the village that the maker and his wife, and perhaps friends who are to help in the work, live in a temporary shelter near the tree. When the tree is felled, it may not lie with the desired side up, and must be rolled over. If it is a very big tree the whole village must be called to roll it - men, women and children. Poles are cut for levers, usually used by the men, while women push directly on the log. Little boys get smaller poles and imitate their fathers. Timed by a grunt word used only in pushing ( $(\mathrm{mmm} »)$, the row of workers rock the log back and forth and then with a big heave roll it over.

The outside of the canoe, called its " bosom », is shaped first, and then the canoe is hollowed out. The greater part of this work is done with the adze. If in the course of hollowing the canoe a serious flaw is found in the wood on the inside, the objectionable part is cut away and a closely fitting block is inset. One to several weeks may be spent in shaping the canoe, depending upon its size, and upon the number of helpers.

The canoe, having been shaped where the log fell, must now be dragged to water. The same poles used as levers in rolling the log may be laid across the path. If the canoe is large, the whole village is again called to help, and again they grunt 'mmm' and push together until the canoe is on the poles. It then slides easily as the poles revolve. The young people snatch up the poles as the canoe passes them and run to replace them in the path ahead. With a great deal of shouting and laughter the canoe is brought down to the river. There dried that is stacked against the sides and set afire. This is called «tempering the canoe ». The saps of the caucho mash [?, pres. caucho masha], lechecaspi, and another tree called pyoji in Piro, are used to repair cracks in canoes.

Usually every family has at least one good large canoe. The young fellows have in addition small, narrow canoes for hunting and fishing. Little boys of ten or twelve may cross the wide river in their own little canoes five or six feet long. (Matteson 1954, pp. 55-56)

Two points from Matteson's account are worth expanding further. The first is that canoe making, and especially the making of large canoes, is initiated almost exclusively by mature men, those over thirty, who can command the necessary work force. The canoe becomes the exclusive property of the initiator, even when he has done relatively little work on it himself. Unlike houses and gardens, ownership of canoes is not shared even with the man's wife. That is, while men tend to identify houses and gardens with their male owner, while women tend to identify them with their female owner, both men and women identify canoes exclusively with their male owner and never with his wife.

Secondly, the cooperation of the whole village in rolling the tree and then in pushing the canoe to water is a very distinctive type of work cooperation in Piro life, and one that is, to my knowledge, associated only with moving canoes. On one occasion during my fieldwork, a group of men were trying to move a large canoe to no avail, when the owner said, « This isn't going to work, brother-in-law, we are going to have to call the women!». When I laughed at this unusual statement, the man said, laughing too, « No, compadre, the women are strong. They will help us move it! ». Which is what happened. This calling of the whole 
village, men, women and children, to help roll or transport the canoe is an image of a social totality usually associated with fun and festivals. This arduous collective effort is, unusually, unreciprocated, although an implicit reciprocation is exacted in the ease and frequency with which canoes are borrowed without their owner's permission. This is considered inconsiderate and irritating, but I have never heard it lead to any more serious recrimination than the whining comment, «You might have told me! $»^{3}$.

The Dominican missionay Álvarez (1970, p. 28) writes,

Each family, and sometimes each member, has a canoe. They are not always very big, the largest are nine to ten metres long by half wide; others, used for fishing, can measure five metres by $40 \mathrm{~cm}$ wide. Their canoe has a special shape: the interior and exterior bases are flat and the sides are at the same level from prow to stern. The woods out of which they are made can be: cedro, caoba, catahua, ishpingo, lagarto caspi, etc.

Half-a-metre wide seems unusually narrow for a canoe of nine to ten metres, but Álvarez is right to note that Piro canoes are, on the whole, very much longer than broad. The narrowness relative to length of Piro canoes can be correlated with the often strong currents with which they have to contend: the Urubamba in flood has a very strong current, and has a high proportion of stones in its load and bed. This latter aspect explains the flat and unusually thick bases of the canoes, which have to resist frequent collision with, and abrasion by, rocks. As a consequence, Piro canoes are remarkably unstable for the unfamiliar traveller.

A point not noted by either Matteson or Álvarez, but which I was able to reconstruct from photographs taken in 1977 of the making of a canoe in Sepahua by Carlos Montenegro, is that this one medium sized canoe was made, so to speak, « upside down », that is the " prow » of the canoe was fashioned from the lower end of the tree, the «stern » from the upper part. Whether this is standard practice is a question for further research.

\section{The NAMing OF THE PARTS}

The Piro language is of the type that used to be called agglutinative, insofar as words are formed out of the affixional expansion of unanalysable word roots, usually of one to three syllables in length. Thus, nkanawate, " my canoe » derives from the unanalysable root kanawa, "canoe ", which can also function as a free-standing word in itself, here with the first person possessive prefix $n$-, and the word-class possessive suffix -te. In what follows, I am exploring a genuine feature of the Piro language and not engaging in spurious etymologization. Where possible, I refer to word roots and affixes identified by the linguist Matteson (1965).

The Piro language has two genders, masculine and feminine. Kanawa, the Piro word for canoe, is grammatically feminine, so all canoe part names take the prefix $t$-/to-, " her ». The canoe has, in fact, relatively few named parts. There is 
tojri, « her nose, the prow », tostsi, « her side, the stern », tospu, « her lips, the gunwales », toswata, « her convex surface, the hull », totlo, « her concavity, the hold or interior » (this also means the cord with which the canoe is made fast to land). The canoe's hold as such, in the sense of where people or things are placed within the canoe, is ganikaji, « half, midst».

There are a number of other items that are often found in a canoe but which are not considered intrinsic to it. These include tokwa, " her floor, the "deck" ", which is a raised platform in the middle of the canoe to keep the cargo from getting wet in the bilge water. This platform, like the seats, tuplapije, are almost never permanently fixed to the canoe, and are often improvised for each new journey. Piro people seem to have an aesthetic dislike of making any permanent attachments of any kind to canoes, even when these might, at least from my point of view, be technically useful ${ }^{4}$. For example, when planning to travel long distances, especially with small children, a roof (kanawa kamatpure; Ucayali Spanish: pamacari) may be constructed over the middle of the canoe, but these always struck me as a little awkward given the absence of any way of attaching the supporting poles of the roof to the body of the canoe itself. Finally, there are two objects essential for canoe travel but which are very definitely not conceived of as parts of the canoe itself. These are the paddle, salwugapi or salogapi, words that shares a root with salwata, «to visit », and the pole for punting, kowigaje. Both of these are possessed by humans, not by the canoe.

I do not think that it is insignificant that canoes are gendered female in the Piro language. The prow as a « nose » and the gunwales as «lips », suggests that the canoe is basically seen as a mouth. Even although the interior of the canoe is totlo, " her concavity », the verb for hollowing out a canoe is jinamga, derived from the root -nama, «mouth ». In Piro, there is a consistent metaphorization of the mouth and the female genitalia, such that «female genitalia » are tonamaji, " her little mouth/her reproductive mouth» (-ji means « seed »). If pressed, I would be willing to bet that the canoe is conceived of by Piro people primarily by analogy to the female genitalia, as is true among the Warao of Venezuela and, to a lesser extent, the Emberá of Panama (respectively Wilbert 1976; Kane 1994). This issue is a question for new research.

Unlike English, but in common with Warao and Emberá, Piro has no specialized language for the parts of canoes, such as «prow» or «stern » or « hold » or " gunwale » in English, in the sense of words that can only be applied to canoes. Canoes are treated, in these languages, as simply one of a series of other objects with certain basic characteristics. This is undoubtedly the result of the absence of canoe-makers or users as a specialized group of people within a wider division of labour (see Simpson 2006 on Gujarati boat-specific vocabulary, boat-builders and crew-formation).

That said, I do not think that the absence of a specialized vocabulary of canoe terms is insignificant. The fact that a canoe has a nose and lips is not evidence of 
a highly undifferentiated and generalized schemata of human bodily metaphors for non-human bodily entities. Instead, I think that the canoe's nose and lips emphasize what differentiates canoes and human bodies, as much as they emphasize what they have in common. People and canoes both have noses and lips, but canoes lack fingers or upper arms, for example, while people lack « empty interiors » (totlo) or « floors » (tokwa).

\section{Prow AND STERn}

Given that kanawa, " canoe », is gendered female, it seems reasonable to call the prow, tojri, « her nose », and the gunwales, tospu, « her lips ». It is less obvious why the stern should be tostsi, « her side». Matteson glosses the root -stsi as « space at the side of, at the point of, nearness, [stern] ». It might be thought that the stern is tostsi in the sense of « at the point of », but in fact most « at the point of »-words in Piro, as one might expect, are related to the word for «nose, prow ». I think that the meaning underlying tostsi for "stern » is the sense of " nearness ». In Piro, « river bank » is rapga-stsi, which we might gloss as « his space at the side of, nearest, to the land » (rivers are gramatically masculine), or, as you can say in English, the water's edge. The water's edge, so to speak, is the river bank seen as an attribute of the river rather than as an attribute of the land. This suggests that, for Piro people, the stern is the edge of the canoe when considering the canoe in motion, on the river: the canoe's stern is to the canoe as the river bank is to the river.

The stern as the canoe's " edge " makes sense when we consider that for Piro people the canoe is fundamentally a vehicle, a vessel for getting from A to B. As such, it is profoundly directional, and its directionality inheres in the axis of prow to stern. When a canoe accidentally looses its moorings and frees itself, it heads downriver spinning aimlessly, with now the prow, now the gunwales, now the stern heading in the direction of movement. The canoe is moving, but to no obvious human purpose: Piro people often say that such a sight makes them feel sad, the opposite of the joys of river travel. To be humanly useful, the canoe should be moving along its prow-to-stern axis under human propulsion, or at least guidance. The prow should be pointed in the direction of travel, and the stern should be at its edge, the distal margin of its centrality.

The canoe is a conceptual mediator between the river and the land. As a long and narrow object, a canoe has two ends, a prow and a stern. The prow is the front, and in Piro conception, the active end of the canoe. The prow defines were the canoe is going, and is therefore its distal end in relation to that movement. The stern is the side or back, and in Piro conception, the passive end of the canoe. The stern defines were the canoe is coming from, and is therefore its proximal end.

Significantly, given that canoes are always docked by the prow, it is the prow that is invariably in contact with dry land, and it is from the prow that they are 
habitually embarked and disembarked. A docked canoe therefore presents its distal extremity first to embarking passengers, who enter it on foot. As the journey commences, the relative positions of prow and stern will invert, such that the initially proximal prow of the embarkation will become the distal prow of the journey, while the intially distal stern will become the proximal stern of the journey. This is experientially true. The beginning of a journey is characterized by a "swinging » movement, as the untied canoe suddenly responds to the river current.

\section{IN THE CANOE}

While not apparently technically necessary, the tojri, "prow », and tostsi, «stern ", of the canoe are always differentiated. The prow is invariably more pointed than the stern. Further, the maximum width of a canoe tends to lie not midway, but towards the stern of the canoe. As I have noted, at the time of my fieldwork, the form of the stern in larger canoes was strongly affected by adaptations for mounting outboard peque-peque motors, in the form of sterns that were left thick in order to accommodate and resist the motor's base (the motors are never permanently attached to the canoe, which would be extremely dangerous were the canoe to capsize, and are usually removed overnight ${ }^{5}$ ). However, a photograph in Álvarez' book shows four canoes in Sepahua before the development of the peque-peque motor. Two have a specific adaptation to the older fuera bordo motor (no longer in existence), while the other two have a flat squared-off extension to the stern that contrasts markedly with the pointed prow. Dole (1998), in her account of the Amahuaca people of Chumichinía Island on the Ucayali mainstream, states that this style is known as "Chama », a term that refers to the Shipibo-Conibo people. I do not remember such canoes from my own period of fieldwork from 1980 onwards, which suggests that the rise of the peque-peque outboard motor had a radical effect on all forms of canoes made by Piro people. The «Chama » canoe seems, from illustrations by Marcoy (1869) in the mid-19th century and accounts by missionary Espinosa (1935) in the early 20th century, to have been the canonical Ucayali-Urubamba canoe.

The flat squared-off extension to the stern has an apparently pragmatic source in the fact that the sternsman paddler needs somewhere to sit. However, such « pragmatic » explanations are often dangerous, given that most small canoes in the 1980's lacked this feature, and that sitting way out over the back of an otherwise unoccupied canoe would make it back-heavy and very hard to control. In my experience, the solitary sternsman of a small canoe has to sit forward of the stern in order to make the canoe manageable. In rivers like the Marañon and the Amazon, where current is much slower than in the Urubamba and Alto Ucayali rivers, the canoe is often paddled from the prow. 
Whatever the utilitarian function of the flat stern extension, if any, it serves to maximally differentiate prow and stern in plastic terms. Significantly, such plastic differentiation is absent in one type of canoe, the kanawa swaga, a small canoe used in the making of manioc beer (called kosho from the Amazonian Quechua). This vessel, while clearly a kind of canoe, is not intended for travelling, and its two ends are undifferentiated into prow and stern. In fact, the plastic modelling give these vessels either two prows and no stern in the manner of the older style, or vice versa, as if to emphasize that they are going nowhere. That said, small children often use kanawa swaga as canoes in play, and I have even seen them actually moving as play canoes in a flooded village.

\section{The Canoe as SOCIAL RELATION}

The Piro canoe instantiates a sociologic, however minimal. While it is technically possible to paddle or pole a canoe alone, and while this is often done, the canoe itself imposes the ideal of a crew of two. This is because, as noted, a canoe has two differentiated ends, a prow and a stern. Even when alone, a Piro person must choose whether to be in the prow or at the stern, for canoes are very seldom paddled or poled exclusively from the middle. Effectively, the choice of prow or stern is made by the means of propulsion: a poler poles from the prow, a paddler paddles at the stern. That is, the lone canœist effectively chooses to be one or other of an ideal of two members of the crew.

I know of no word in the Piro language that would correspond to the English word « crew », in the sense of a specific set of social relations that are linked to a specific « craft ». Piro people formulate the sociology of canoe travel in a more terse form, in the distribution of two key activities, wajrita, " to do the prow », and wastsita, " to do the stern ». Usually, but not invariably, this difference reflects modes of propulsion: one person «does the prow » with a punt pole, while the other "does the stern » with a paddle. It is possible, and sometimes technically desirable, for both the prow and the stern to be done with poles or paddles. When seeking to go upriver fast, it is desirable for the persons in both the prow and the stern to pole, since poling is more effective than paddling. When going downriver, it is desirable to travel in the fast-flowing and deep main channel of the river, where poling is impossible. In all cases, however, it is the one who « does the prow » who is initiating the movement, while the one who " does the stern $»$ who is adjusting his/her actions accordingly. In the definition of the verb wajrita, the Diccionario Piro offers the following example, wajrita jeji; ganunro wastsita. The man does the prow/« prows »; his wife does the stern/« sterns » (Nies 1986). The canoe is the technical instantiation of a social relation, in this case, a marriage. In fact, the man-in-the-prow and the woman-in-the-stern is a special condition of a more profound division. 
In the most common form of canoe journey, the fishing trip, a man might well be accompanied by his wife who " sterns » for him, but only when she is unencumbered by the care of a small child. Young children are seldom taken onto the river, and never at night, when much fishing takes place. Much more commonly, a man going fishing is accompanied by a sub-adult coresident brother-in-law, a sub-adult son, or more rarely a sub-adult younger brother, who "sterns » for him. Significantly, adult brothers very seldom fulfil the prow/stern relation, despite the importance of the older/younger sibling relationship. Nor do adult brothers-inlaw, who are facultative equals, do so. My impression is that the "normative " prow/stern social relation in the most everyday of canoe journeys, the fishing trip, is an adult man in the prow and his coresident wife's sub-adult brother in the stern.

This suggests that the key sociology of the Piro canoe lies in the affinilization of prow/stern, male/female, older/younger relations. Álvarez (1970, p. 28) provides a rather different account,

In Piro navigation, the crew have their specific tasks, either in the prow or in the stern. The one who goes in the stern must be an older person, of higher status. This task would correspond to old people, but if there are women, the oldest will take the stern, and the rest of the men will take the prow. When the journey is long and it is necessary to stay on the beaches, tasks are divided as follows: the first man in the prow must tie up the canoe securely and take care of it at night; the rest should fish or hunt and gather firewood; the one in the stern should cook.

There are certain problems with Álvarez' account, which could only be ressolved if it were the case that Piro people habitually think of women as older than, and hence senior, to men. The quote from the Diccionário Piro and my own ethnography, suggest that this is not true. The prow is consistently assigned to the strongest poler in Piro people's conception, and other roles are distributed on that basis. That said, I think that Álvarez' account does reveal an important feature of the sociologic of Piro navegation. Energetic younger men are at the front of the canoe, while older men, women or boys are in the stern.

This raises a key sociological issue. Everyday Piro social life is ordered by older/younger consanguineal relations between women, those between mothers and daughters, and between older and younger sisters. Men attach themselves to these older/younger female consanguineal relations as husbands, brothers, fathers and sons. Men remain relatively peripheral to houses, and their own older/younger consanguineal relations become almost invisible after they achieve adulthood. By contrast, male-on-male affinal relations dominate the life of the village as a whole, and, as we have seen, are the very model of the sociology of the canoe. In turn, nothing prevents a mother and daughter, or two sisters, from crewing a canoe, but it would hardly be viewed as a very desirable situation, or of great sociological import. 


\section{IN THE MIDDLE}

If the canoe has its poles of tojri, " prow », and tostsi, "stern », and associated social relations, then someone, or something, is " in the middle », ganikaji. This « in-the-middle-ness » is derived from a verb root, ganika, " to take with, to carry ». This was the second verb I ever learned in Piro, after gaylota, « to lie », given that " ipanikanru! ", " take him with you, carry him! » (Ucayali Spanish: " illevale! ») is the virtual refrain of every Piro mother with a growing brood of children. " ;Panikanru! " is said in response to the endlessly repeated scenario where an older sibling begins to move away from a toddler on some project that he or she does not want this younger sibling involved in, which causes the toddler to burst into tears. " Take him with you! », the mother responds in the high, thin, vocal register of intense respect between kinspeople, meaning, "your younger sibling is your responsibility right now, not mine! ${ }^{6}$. « To be carried, to be taken with » is therefore a emotionally highly-charged relation for Piro people. The key reference for ganikaji, « in-the-middle-ness », is therefore to a small child.

This, however, is only the beginnings of an understanding of the conception of « in the middle of the canoe » for Piro people. I noted above that, while Piro people readily conceive of the prow/stern relation in terms of the husband/wife relation, this specific combination is not the most common social instantiation of the prow/stern relation in the most common form of the canoe journey, the fishing trip. There the prow/stern relation is primarily instantiated as the senior male affine/junior male affine relation, especially in its form of adult brother-inlaw/sub-adult brother-in-law. In this canoe journey, what is " in the middle », ideally at least, is the catch of fish, not a child. As a successful fishing expedition proceeds, the dead or merely immobilized fish accumulate « in the middle » of the canoe, which effectively turns into a container of caught fish.

More generally, that which is ganikaji, " in the middle », is by definition « being taken with, being carried » rather than taking any active part in propelling the canoe: that which is " in the middle » is by definition neither engaged in " doing the prow » or " doing the stern ». This leads to an important consequence: while the prow and stern are necessarily occupied by people while the canoe is moving, for its is those « doing the prow » and " doing the stern » who are moving and guiding the canoe, the « middle » need not be occupied by people, since this spatial location is not involved in causing the canoe to move. The prow and stern are the agentive positions of the canoe, while the "middle " is its passive position. While the agentive positions must be occupied by humans (or in myth, by humanoids), the passive position does not need to be occupied by humans, and very often is not.

I return to this issue later, but here note one of the most surprising things that can be in the « middle » of a canoe: fire. When travelling long distances and when 
they are in a hurry, Piro people sometimes make cooking fires in their canoes so that they can cook food and travel at the same time. The hull of the canoe is protected from the fire by a thick layer of earth, a technique also used when building fires on the palmwood platform floors of houses. As such, Piro people do not think of canoes and fire as radically disjunct, and even see canoes as potential containers of fire, an image repeated in their myths about the journey of the sun (Gow 2001). It is also likely that in the past, before easy access to adzes (or today chainsaws), fire was used to hollow out the canoes (see Marcoy 1869 on canoemaking among the neighbouring Conibo).

The Piro canoe has a key apparent paradox, which it shares with all vessels of transport: while the Piro canoe is clearly designed for movement, for travelling, its internal spatial confirgurations are unaffected, one might even say totally unmoved, by its exterior displacement. That is, no matter how far a canoe travels, or in what direction, its interior prow-middle-stern spatial and social relations are unaffected. The canoe and its contents, human and otherwise, move with respect to the wider landscape, but not with respect to each other.

\section{To STAY}

This last point, which might seem trivial, indeed utterly self-evident, gains meaning if it is compared to the Piro spatial icon of « staying » ( $g w a-)$, that is, houses and villages. In many indigenous Amazonian societies, such as those of the Northwest Amazon or Central Brazil, houses and/or villages are marked by high degrees of symbolic spatial differentiation with a considerable social weight. Piro houses and villages, however, are not characterized by high degrees of internal spatial differentiation. Houses are often divided into areas reserved for cooking, for eating and socializing, and for sleeping, but such spatial divisions are easily broken down in the ceaseless building, destruction and re-building to which Piro houses are subjected. Equally, none of the spatial divisions of a house operate as signifiers of social positions associated with gender, age or kinship status. I cannot imagine any Piro person replicating the pithy condensation of social relations onto spatial relations quoted above for canoes in the context of the house. Even if Piro women spend much of their time in the kitchen area of the house, it would be meaningless for Piro people to say, for example, « the place of the woman is in the kitchen ".

Similarly, Piro villages show no high degree of internal spatial complexity. Piro people do try to build their houses in what to them, and to me, are aesthetically pleasing forms, with regular spacing between them and a general alignment of orientation. For example, they try to align the long axes of houses, the ridge poles, to each other and to the course of the river. In villages such as Bufeo Pozo this leads to impressively long and straight lines of houses stretching 
along the riverbank. However aesthetically pleasing, there is no evidence that such alignment means anything much more than the dramatic expression of a village's esprit de corps.

By contrast, the canoe is internally highly differentiated and specified, with prow, middle and stern, each associated with specific kinds of social relations, and concatenations of social relations. It would seem that the canoe operates for Piro people as the house or village layout does for the peoples of the Northwest Amazon and Central Brazil, that is, providing a complex «map » of social relations as locii within a bounded space. Of course, the canoe is a vessel for movement, for journeying, and it does not seem trivial to me that Piro people have invested their canoes, rather than their houses or villages, with a high degree of socio-spatial symbolic elaboration. Arguably, it is in the canoe, and indeed in the canoe in motion, that Piro social structure is most clearly given spatial form. This is because the journey is intrinsic to the way in which Piro people understand their social lives.

When talking of the major ritual performance of Piro people, kigimawlo, " girl's initiation ritual », people will say, « all of the Piro people from along the river are invited ». This is an image of social totality, as « all of the Piro people» scattered among the various villages along the Urubamba converged as guests on the " big house » built by the hosts to celebrate a girl's emergence from her prolonged puberty seclusion (Gow 2001). This puberty seclusion, initiated by a girl's first menstruation, is the most intensified form of "staying " for Piro people, for, ideally, the girl gitoko twa, « stays inside (the house) » for a year. Her emergence, her re-initiation of movement, causes all the Piro people to journey by canoe to witness it. As the Piro hypostasis of immobility, the secluded girl highlights the importance of travel, and its irresistable pleasures, for Piro people.

\section{Transforming THE MIDDLE}

This paper has been a preliminary ethnographic account of the Piro canoe, and could be extended almost indefinitely in many directions through the Piro lived world. As I noted above, it would be possible to do for canoes what I did for yonchi, "design », and women elsewhere (Gow 1999, 2001), and hence to fully explore the implications of canoe-making, use and unmaking ${ }^{7}$ for the life-course of Piro men. And it would be extremely productive to follow the lead of LéviStrauss, noted above, and explore the meaning of canoes, canoe journeys, etc. through Piro mythology and then back to Piro everyday life.

In conclusion I want to briefly discuss one specific historical feature of these canoes. I have not here discussed in any detail the very feature of Piro people's lives that led me to the topic of canoes in the first place: their system of long distance trading in the 19th century and the internal transformations that lead to 
its abandonment in the early 20th century due to transformations in its wider regional and global conditions. At the outset of the research, I realized that the topic was very large and complex, but as I did the research I quickly realized that the archival data I was investigating was not providing me with the kinds of insights I was looking for. Nowhere in the archive could I find any accounts of what really motivated Piro people to engage in journeys like the following: until 1912, people from the Bajo Urubamba would regularly spend two to three months ascending the Urubamba river, up through the narrow canyon of the Pongo de Mainique then through nine sets of very dangerous rapids to trade with Andean people at El Encuentro on the Alto Urubamba. We can read about what they traded with and what they traded for, but we can find no contemporary Piro accounts of what motivated them to make such arduous and dangerous journeys. A late 20th century mythic narrative of such a canoe journey for trading exists (see Matteson 1965, pp. 210-215; and Gow 2001, pp. 203-208), but this would require separate ethnographic and historical analysis. Most 19th century sources record Piro people's avid desire for metal tools, but three to four months hard work seems a very high opportunity cost, as the economists say, for such tools. Equally, Urubamba Piro people were very reluctant to allow Franciscan missionaries to found effective missions in their territory, even though this would have meant that the costs of metal tool transportation would then have been shifted to the Franciscans.

My account here of the Piro canoe provides, I think, a substitute for the absent Piro testimony on their motivations for long distance trade. Firstly, I have argued that the canoe is a privileged spatial condensation of key social relations for Piro people. Further, the canoe internally orders these social relations spatially as an opposition between a prow/« going » pole and a stern/« staying » pole, poles which are in turn respectively ordered by that of strong younger men versus older men, women and boys. Equally, we have the mediating role of ganikaji, « in the middle (of the canoe) ». That which is in the middle of the canoe intrinsically mediates between the prow and the stern, and who is located at each. Further, on the outward bound journey, it is the prow that points towards, and hence is closer (however minimally) to the destination in the lands of other people, while on the homeward bound journey, this function inverts to the stern. In this process, all of the social meanings of the prow and stern invert during the journey in relation to the distant Other. As Piro trading canoes arrived in the places of the targeted others, what these latter saw where the vigourous younger male polers from the front. As the trading canoe departed, the others would have seen the backs of old people and/or women.

The most dramatic transformation was in the "middle». As noted, the position of the « middle " never varies with relation to the prow and stern, and the same is logically true of the outward and homeward journeys, since the « middle » always stays in the middle. But the contents of the " middle » are 
totally different between the two journeys. In the «middle » on the outward journey are wealth items present at home, which are known to be desired by the distant Other. In the "middle" on the homeward journey are wealth items present among the distant Other, which are desired by Piro people. I give an example. In 1843, Valdéz y Palacios (1971, p. 98) reported that thirty canoe loads of Piro people arrived at El Encuentro, at the juncture of the Urubamba and Yanatile rivers, and wrote,

Various tribes of savages belonging to the Antis and the Chontaquiros... go in some years to the Mission [of Cocabambilla] in the dry season, bringing parrots, macaws, robes (the clothing of savages), cedarwood canoes, slave women from other tribes, wild cacau, rubber, resins and other desired things, which they exchange for knives, machetes, pieces of mirror, scissors, nails, salt, etc. It is most curious to see this fair.

In effect, the « Chontaquiros » (Piro people) bring forest products up to the Andean traders gathered at El Encuentro, and trade them for metal goods (yowuma) and salt only: there is no evidence that Piro people ever had any general interest in other Andean products. In the case of the El Encuentro trade, the diversity of forest products in the " middle» of the Piro canoes was traded for metal goods and salt, which then replaced the forest products in the « middle » for the return journey. This trade could even include the canoes themselves, given that the goods acquired were much less bulky than those brought, and hence left room for more people.

Unfortunately, we know much less about other nodes of this trading system. We know that Urubamba Piro traded with the Manitineri on the Purús for cotton cloth (Chandless 1866), and presumably offered metal goods and salt in return. Unfortunately, that is about all we know. That said, the process by which the canoes of Piro traders would " disgorge » themselves of one set of valuables to " engorge » themselves with others is a striking feature of these canoes, and Piro trading in general. The metaphor of excessive eating is my own, but not, I think, totally alien to Piro thought. Swallowing and vomitting are important metaphors in Piro thought, including in images of long-distance movement and irreversibe change (see Gow 2001). Unlike a living Piro person, a canoe has no guts, and is thus capable of endless filling, emptying and re-filling with wealth items as these are ferried about to those who most desire them. The "middle " of the canoe, this cavity without guts, becomes the key transformational container of a vast trading network. It is the poles of this cavity, the prow and stern, and their associated social positions, that render it mobile through a vast landscape, and potently effective.

Until the first decade of the twentieth century, the Piro people were renowned as long distance traders, undertaking extraordinary journeys that lasted for months and were often both very arduous and very dangerous. It seems likely to me, from the data provided here, that these trading expeditions were not simply a 
response to some necessity (distant sources of desired goods), but a genuine social value of Piro society, much like Malinowski's analysis of the kula (Malinowski 1922), or Turner's account of Gê-Bororo trekking (Turner 1979). The trading expeditions would have called into play all the complex social meanings of the canoe and the wider landscape of river journeys and of social and natural calendars. And such travel was, we know, irresistibly pleasant to Piro people.

\section{Conclusion}

Ethnographic accounts like the present, and especially preliminary ones, do not lend themselves well to conclusions. As noted above, the present work was written largely to stimulate other ethnographic accounts from the ethnographers of other peoples. So, by way of conclusion, I will note two sets of connections that may help other ethnographers to think about their own data.

Firstly, canoes are containers, of people and things, and belong within the complex category of containers and contents explored for indigenous American thought in such detail by Lévi-Strauss in the Mythologiques. In the Piro case, the kanawa swaga, the small canoe for beer-making, forms a logical bridge between the canoe and pottery cooking and storage vessels. The association of canoes and cooking reappears constantly throughout the Americas, and certainly would benefit from closer scrutiny. But canoes, like pottery vessels, can be inverted, when they cease to be containers. In the Piro case, rotting canoes are often floated into the village during flooding, where they are turned upside down for use as outdoor seating in clement weather. Canoes therefore are a kind of stool. While this is not elaborated in the Piro case, because they do not really make stools, it is elaborated among the Yudjá of the Xingu river, who makes stools out of the parts of the trunk left over from canoe-making (Tania Stolze Lima, personal communication). The canoe is therefore a kind of inverted stool, an idea that received complex elaboration among the Apapocuva people (Nimuendajú 1987). The paths of enquiry multiply.

Secondly, the Piro words for travel, yagapota, " to travel by trail », and yagapgata, " to travel by river, to journey », contain the root gapo, which I translated as «way ». If the canoe is the medium of travel of yagapgata and substrate of such travel is gapga, " river », then, logically, the gatnu gapo, " path », is the medium of travel of yagapota and the substrate of such travel is gosha, the « forest ». We could represent this as follows:

\section{River:Forest::Canoe:Path}

This immediately brings to mind certain key dichotomies in anthropological accounts of indigenous Amazonian peoples, but it does so in a novel form. Where for Meggers and Lathrap and their followers these dichotomies were natural, here 
we see them as both technological and meaningful. Even the most cursory familiarity with the ethnography of indigenous Amazonian peoples attests to the extraordinary proliferation of path imagery in their thoughts about the world, but one would look in vain for anything more than very brief discussions of path technology. In Amazonia, paths must by made and maintained. So, a preliminary ethnographic study of the Piro canoe opens questions for regional specialists working with peoples who do not even make or use canoes. *

* Manuscrit reçu en avril 2010, accepté pour publication en décembre 2011.

\section{Notes}

Acknowledgments: The ethnographic and ethnohistorical research has been funded by the then Social Science Research Council of Great Britain, the British Academy, the Arts and Humanities Research Board of Great Britain, the University of Manchester, the London School of Economics and the University of St Andrews. My first thanks are to Edward Simpson, for introducing me to the importance of the anthropology of long-distance freight haulage contractors, through his work in Gujarat, India. Steve Hugh-Jones, Tania Stolze Lima, Philippe Erikson, Paolo Fortis, Margherita Margiotti, Minna Opas and Pirjo Virtannen generously shared their own knowledge of the topic in response to my growing enthusiasm, and Isabelle Daillant made a key point about rafts from her Chimane materials, while Margaret Willson gave excellent advice from a practioner's perspective. Nancy J. Munn would, I hope, recognize her continuing influence on my thinking, and my commitment to a certain style of anthropology. My ongoing debts to the people of the Bajo Urubamba are, I hope, obvious, and I thank them for their inordinate patience in introducing me to their canoes and to their lives, and how these are bound up together. In particular, I remember that remarkable day when Don Mauricio Fasabi, himself a former novice in the world of Piro canoes, trusted me enough to « do the stern » as we ventured to cross the very wide Urubamba river in full flood.

1. I am grateful to Philippe Erikson for providing me with a copy of this manuscript.

2. Interestingly, the extensive literature on Melanesian canoes focuses almost exclusively on outrigger canoes such as those of Gawa, and there is even extensive debate about why such canoes are absent or almost absent in the Americas. This seems to me to be asking the wrong question.

3. Canoes are also regularly stolen, but only by travellers from very distant communities who feel that they are unlikely to get caught.

4. The only common exceptions are a small cross-bar nailed to the interior immediately aft of the prow for tying the rope to, and the metal plate on which the motor will sit, which is nailed to the upper side of the stern.

5. In towns, where it would be impractical to remove the motor, canoes are always left in the care of a trusted person, who may charge for the service, at least by insisting that any fuel is purchased from him or her. If staying overnight in such a situation, the owner of the motor will often sleep in the canoe.

6. I do not apologize for the implicit gendering of this process, for I cannot call to mind examples of older siblings being called to take an undesired younger sister with them. I do, however, apologize for my failure to theorize this apparent difference.

7. Many Piro canoes, at the end of their careers, are chopped up to make coffins, and it is likely that in earlier times the unmodified canoe served this purpose for burying adults: children were, I was told, buried in large pots beneath their mothers' cooking fires. 


\section{REFERENCES CITED}

Álvarez Ricardo

1970 Los Piros: hijos de dioses, Heraclio Fournier S.A., Lima.

CHANDLESS William

1866 «Ascent of the river Purus », Journal of the Royal Geographical Society, 35, pp. 86-118.

DoLe Gertrude E.

1998 «Los amahuaca », in Fernando Santos and Frederica Barclay (eds), Guía etnogáfica de la Alta Amazonía. Vol. 3. Cashinahua, amahuaca, shipiboconibo, Smithsonian Tropical Research Institute, Panama/ Ediciones AbyaYala, Quito.

EsPINOSA Lucas

1935 Los tupí del Oriente peruano: estudio lingüístico y etnográfico, Librería y Casa Editorial Hernando, Madrid.

Gow Peter

1991 Of mixed blood: kinship and history in Peruvian Amazonia, Oxford University Press, Oxford Studies in Social and Cultural Anthropology, Oxford.

1999 "Piro designs: painting as meaningful action in an Amazonian lived world », Journal of the Royal Anthropological Institute (n.s.), 5, pp. 229-246.

2001 An Amazonian myth and its history, Oxford University Press, Oxford.

KANE Stephanie C.

1994 The phantom gringo boat: shamanic discourse and development in Panama, Smithsonian Institution Press, Washington/London.

LÉvi-STRAuss Claude

1978 The origin of table manners, London, Jonathan Cape [French edition : L'origine des manières de table, Plon, Paris, 1968].

LowIE Robert H.

1948 "The tropical forests: an introduction », in Julian H. Steward (ed.), Handbook of South American Indians. Vol. 3. The tropical forest tribes, Bureau of American Ethnology, Washington.

MALINowsKi Bronislaw

1922 Argonauts of the Western Pacific: an account of native enterprise and adventure in the archipelagoes of Melanesian New Guinea, George Routledge and Sons, London.

Marcoy Paul

1869 Voyages à travers l'Amérique du Sud: de l'océan Pacifique à l'océan Atlantique, 2 vol., Hachette, Paris.

1875 Travels in South America: from the Pacific Ocean to the Atlantic Ocean, Scribner/Armstrong and Co, New York. 


\section{MATTESON Esther}

1954 «The Piro of the Urubamba », Kroeber Anthropological Society Papers, 10, pp. 25-99.

1965 The Piro (Arawakan) language, University of California Press, Berkeley/Los Angeles.

MunN Nancy D.

1977 "The spatiotemporal transformations of Gawa canoes », Journal de la Société des Océanistes, 33, pp. 39-54.

1986 The fame of Gawa: a symbolic study of value transformation in a Massim ( Papua New Guinea) society, Cambridge University Press, Cambridge.

NiEs Joyce (ed.)

1986 Diccionario Piro (Tokanchi gikshijikowaka-steno), Ministerio de Educación y Instituto Lingüístico de Verano, col. «Lingüística Peruana »22, Yarinacocha.

NimuendaJú Curt

1987 As lendas da criação e destruição do mundo como fundamentos da religião dos Apapocúva-Guarani, HUCITEC/Editora da Universidade de São Paulo, São Paulo.

Roop Wendell T.

1935 Watercraft in Amazonia, Woodbury, New Jersey [unpublished manuscript].

Simpson Edward

2006 Muslim society and the Western Indian ocean: the seafarers of Kachchh, Routledge, London.

STEWARD Julian H.

1949 "Preface », in Julian H. Steward (ed.), Handbook of South American Indians. Vol. 5. The comparative ethnology of South American Indians, Bureau of American Ethnology, Washington.

TURNER Terence $\mathrm{S}$.

1979 «The Gê and Bororo societies as dialectical systems: a general model », in David Maybury-Lewis (ed.), Dialectical societies: the Gê and Bororo of central Brazil, Harvard University Press, Cambridge Mass./London.

Valdéz y Palacios José Manuel

1971 Viaje del Cuzco a Belén en el Gran Pará (por los rios Vilcamayo, Ucayali e Amazonas) (1844), Biblioteca Nacional del Perú, Lima.

WILBERT Johannes

1976 «To Become a maker of canoes: an essay in Warao enculturation », in Johannes Wilbert (ed.), Enculturation in Latin America, UCLA Latin American Center Publications, Los Angeles. 